\title{
Growth retardant and nitrogen levels in wheat agronomic characteristics
}

\section{Redutor de crescimento e doses de nitrogênio em características agronômicas do trigo}

\section{Felipe SCHWERZ1'; Braulio Otomar CARON²; Denise SCHMIDT ${ }^{3}$; Douglas Machado de OLIVEIRA ${ }^{4}$; Elvis Felipe ELLI ${ }^{4}$ Elder ELOY5; Ana Paula ROCKENBACH ${ }^{6}$}

\begin{abstract}
${ }^{1}$ Autor para correspondência; Acadêmico do curso de Agronomia; Centro de Educação Superior Norte - RS, Universidade Federal de Santa Maria; Departamento de Ciências Agronômicas e Ambientais; Linha Sete de Setembro, s/n, - BR 386 km 40, CEP 98400-000, Frederico Westphalen/RS. felipe_schwerz@hotmail.com

${ }^{2}$ Engenheiro Agrônomo, Dr., Professor do Centro de Educação Superior Norte - RS, Universidade Federal de Santa Maria; caron@smail.ufsm.br

${ }^{3}$ Engenheira Agrônoma, Dra., Professora do Centro de Educação Superior Norte - RS, Universidade Federal de Santa Maria ; denise@ufsm.br

${ }^{4}$ Acadêmico do curso de Agronomia, Centro de Educação Superior Norte - RS, Universidade Federal de Santa Maria; douglas.mdo@hotmail.com; elvis_elli@hotmail.com

${ }^{5}$ Engenheiro Florestal, Doutorado em Engenharia Florestal, Universidade Federal do Paraná; elderreloy@hotmail.com

${ }^{6}$ Engenheira Agrônoma; Mestranda do Programa de Pós Graduação em Agronomia, Agricultura e Ambiente do Centro de Educação Superior Norte - RS, Universidade Federal de Santa Maria; anapagronomia@yahoo.com.br
\end{abstract}

Recebido em: 10-06-2014; Aceito em: 24-11-2014

\begin{abstract}
Facing the use of high rates of nitrogen $(\mathrm{N})$ fertilizer in wheat crop, the importance of the use of plant growth regulators is observed, and it has become important technology to improve the production efficiency of various species of plants. Thus, we aimed at evaluating the effect of $\mathrm{N}$ fertilization, with Sulfammo ${ }^{\circledR}$, and the use of growth reducer on the agronomic traits of wheat cultivars. The work was conducted in the experimental area of the Federal University of Santa Maria, Frederico Westphalen campus, in the period from 06 June to 20 October 2012. The soil in the area is classified as dystrophic Red Latosol and the experimental design was a randomized complete block in a 3×5×2 factorial, with three cultivars (TBIO Mestre, TBIO Iguaçú e TBIO Itaipú), five rates of $\mathrm{N}\left(0,40,80,120\right.$ and $\left.160 \mathrm{~kg} \mathrm{ha}^{-1}\right)$ and application or not of growth reducer (trinexapac-ethyl) at a dose of $100 \mathrm{~g} \mathrm{ha}^{-1}$, with three replications. The growth reducer reduces the length of the second and third internode to the TBIO Itaipú and TBIO Iguaçu, the total biomass of the plant, increases thousand grain weight and increases the number of spikelets per spike in TBIO Itaipú. Increasing the rates of $\mathrm{N}$ as Sulfammo ${ }^{\circledR}$ allows increasing the length of the first, second and third internodes, culm length, ear length and mass of the spike.
\end{abstract}

Additional keywords: nitrogen fertilization; Triticum aestivum L.; yield components.

\begin{abstract}
Resumo
Frente à utilização de elevadas doses de adubação nitrogenada na cultura do trigo, observa-se a importância do uso de reguladores de crescimento vegetal, sendo que o mesmo tem se tornado tecnologia importante para melhorar a eficiência produtiva de várias espécies de plantas. Assim, objetivou-se avaliar o efeito de doses de adubação nitrogenada, na forma de Sulfammo ${ }^{\circledR}$, e a utilização de redutor de crescimento nos caracteres agronômicos de cultivares de trigo. $\mathrm{O}$ trabalho foi realizado na área experimental da Universidade Federal de Santa Maria, campus de Frederico Westphalen, no período de 6 de junho a 20 de outubro de 2012. O solo da área é classificado como Latossolo Vermelho distrófico típico e o delineamento experimental utilizado foi o de blocos casualizados, em esquema fatorial, sendo três cultivares (TBIO Mestre, TBIO Iguaçú e TBIO Itaipú), cinco doses de nitrogênio $\left(0,40,80,120\right.$ e $\left.160 \mathrm{~kg} \mathrm{ha}^{-1}\right)$ e aplicação ou não do redutor de crescimento (trinexapac-ethyl), na dose de $100 \mathrm{~g} \mathrm{ha}^{-1}, \mathrm{com}$ três repetições. O redutor de crescimento reduz o comprimento do segundo e terceiro entrenó nas cultivares TBIO Itaipú e TBIO Iguaçú, a fitomassa total da planta, aumenta a massa de mil grãos e incrementa o número de espiguetas por espiga na cultivar TBIO Itaipú. O aumento da dose de $\mathrm{N}$ na forma de Sulfammo ${ }^{\circledR}$ possibilita o aumento do comprimento do primeiro, segundo e terceiro entrenós, comprimento de colmo, comprimento da espiga e massa da espiga.
\end{abstract}

Palavras-chave adicionais: adubação nitrogenada; componentes da produção; Triticum aestivum L. 


\section{Introduction}

Wheat (Triticum aestivum L.) is the largest source of calories and protein to the world population, being a culture of a great importance for Brazil, with a growing demand for its oil. The Brazilian production of wheat is around 5 million tons per year, well below the annual wheat demand, which is 10 million tons. The technologies currently employed enabled an average productivity of $700 \mathrm{~kg} \mathrm{ha}^{-1}$, in the 1940 , to reach 2,140 kg ha-1 (CONAB, 2013).

There are several features that can be manipulated in wheat crop that result in grain yield increase. For example, the increase in the number of grains per area, in the harvest index, an increased optimization of the ear and a maximized capacity and photosynthetic efficiency (Foulkes et al., 2011; Parry et al., 2011).

The interest in maximizing wheat yield has encouraged the adoption of intensive crop management practices, in which the use of high doses of nitrogen fertilization and the use of plant growth regulators are highlighted. This has become an important technology to improve production efficiency of various plant species, among which wheat (Vieira et al., 1995).

Among management practices, the fertilization with nitrogen $(\mathrm{N})$ is underlined because it is the most required element by the culture, knowing that the soil does not normally provide sufficient quantities of it for cultivation and present positive responses in grain productivity. If the deficiency of this element is observed, the culture will tend to reduce its biomass production and its solar radiation use efficiency, with a great effect on grain yield and its components (Heinemann et al., 2006; Kutman et al., 2011).

The use of slow-release fertilizers, among them Sulfammo ${ }^{\circledR}$, in which $\mathrm{N}$ protection is performed through a nitrification inhibitor such as, for example, 3,4-dimethilpirazolfosfate (DMPP). It prolongs the $\mathrm{N}$ time in a non-leachable form $\left(\mathrm{NH}_{4}^{+}\right)$, allowing an adequate supply of $\mathrm{N}$ throughout the crop cycle and the reduction of leaching losses (Zerulla et al., 2001). In this context, the use of Sulfammo ${ }^{\circledR}$ becomes an interesting alternative to supply an $\mathrm{N}$ deficiency, and this fertilizer allows nutrients to be available continuously to plants, minimizing the risk of nutritional deficiencies throughout the crop cycle.

Among the strategies associated with the use of high doses of $\mathrm{N}$ in wheat are the use of short cultivars or the application of growth retardants, among which trinexapac-ethyl, an growth retardant that interferes at the end of the metabolic pathway of the biosynthesis of gibberellic acid (Heckman et al., 2002) by inhibiting the enzyme 3 beta-hydroxylase, drastically reducing the level of active gibberellic acid $\left(G A_{1}\right)$ and thus markedly increasing its biosynthetic immediate precursor $\mathrm{GA}_{20}$ (Davies, 1987).

Thus, the use of trinexapac-ethyl has been emphasized due to its ability to reduce plant height, improve leaf architecture of wheat and increase culm diameter, reducing the lodging and optimizing the use of solar radiation. Consequently, it increases productivity (Zagonel \& Fernandes, 2007). Even in cultivars that have a reduced size, the application of growth retardants enabled positive results. With it, the plant shows a better leaf architecture and consequently a higher uptake of radiation due to the increase in the number of fertile tillers and a higher redirection of photoassimilates toward grain production, to the detriment of the development of the culm (Matysiak, 2006; Zagonel \& Fernandes, 2007).

Assuming that the factors mentioned above are able to modify morphological and productive characteristics of the wheat crop and that their effects are influenced by the characteristics of the growing area, as well as by the cultivars used, it is necessary to quantify and characterize these effects in order to obtain satisfactory results related to the agronomic characteristics of this culture. Thus, the objective was to evaluate the effect of nitrogen fertilization doses using Sulfammo ${ }^{\circledR}$ and the use of a growth retardant on agronomic traits of wheat cultivars.

\section{Material and methods}

The study was conducted in the experimental area belonging to the Agroclimatology Laboratory of the Federal University of Santa Maria (UFSM), Frederico Westphalen campus, located in northern Rio Grande do Sul, Brazil, with geographic coordinates $27^{\circ} 23^{\prime} 48^{\prime \prime} \mathrm{S}$, $53^{\circ} 25^{\prime} 45^{\prime \prime} \mathrm{W}$ and altitude of $490 \mathrm{~m}$. According to the Köppen climate classification, the area's climate is Cfa. Frederico Westphalen is about $30 \mathrm{~km}$ far from Iraí, and the city was taken as a reference to the climatic classification data. As proposed by Maluf (2000), Iraí presents a subtemperate sub-humid climate, with an average annual temperature of $18.8^{\circ} \mathrm{C}$ and the average temperature of the coldest month $13.3^{\circ} \mathrm{C}$.

The study was conducted in the period from June 6 to October 20,2012. The soil of the area is classified as typical dystrophic Red Latosol, clayey, deep and well drained (Embrapa, 2006). It presented the following chemical characteristics: $\mathrm{pH}$ in water: 6.0; $\mathrm{P}$ (Mehlich): $3.0 \mathrm{mg} \mathrm{dm}^{-3} ; \mathrm{K}: 160 \mathrm{mg} \mathrm{dm}^{-3}$; Ca: $6.2 \mathrm{cmol}_{\mathrm{c}} \mathrm{dm}^{-3}$; $\mathrm{Mg}: 3.3 \mathrm{cmol}_{\mathrm{c}} \mathrm{dm}^{-3}$; Al: $0.0 \mathrm{cmol}_{\mathrm{c}} \mathrm{dm}^{-3}$; CTC: $9.9 \mathrm{cmol}_{\mathrm{c}} \mathrm{dm}^{-3}$; base saturation: $76 \%$; and organic matter: $3.1 \%$. The experimental design was made with randomized blocks, in a $3 \times 5 \times 2$ factorial design, with three cultivars (TBIO Mestre, TBIO Iguaçú and TBIO Itaipú), five $\mathrm{N}$ doses $(0,40$, 80,120 and $160 \mathrm{~kg} \mathrm{ha}^{-1}$ ) as Sulfammo ${ }^{\circledR}$, and the application or not of the growth retardant (trinexapac-ethyl), with three replications. The size of each plot was six rows of three meters long, each spaced $17 \mathrm{~cm}$.

The sowing was manually held on June 6 , 
2012 three centimeters deep and with a density of 350 seeds $\mathrm{m}^{-2}$. The fertilization was made with potassium $\left(\mathrm{K}_{2} \mathrm{O}\right)$ at the sowing, in the amount of $30 \mathrm{~kg} \mathrm{ha}^{-1}$, and phosphorus $\left(\mathrm{P}_{2} \mathrm{O}_{5}\right)$ at a dosage of $65 \mathrm{~kg} \mathrm{ha}^{-1}$, according to the results of soil analysis and following technical indications of the Comissão de química e fertilidade do solo (2004). At the time of seeding, a nitrogen fertilizer at a dose of $20 \mathrm{~kg} \mathrm{ha}^{-1}$ was also used and the remaining was used as coverage in the early tillering stage. The weed control was performed through a manual weeding at 20 days after emergence (DAE).

The gradual release of commercial Sulfammo ${ }^{\circledR}$ was used as a source of $\mathrm{N}(26 \% \mathrm{~N}+5 \%$ $\mathrm{Ca} ; 9 \% \mathrm{~S}, 2 \% \mathrm{Mg}$ and $0.3 \% \mathrm{~B})$. The growth regulator used was trinexapac-ethyl, applied at a dose of $100 \mathrm{~g} \mathrm{ha}^{-1}$ through a backpack sprayer with an average application speed of $5.5 \mathrm{~km} \mathrm{~h}^{-1}$, with a proportion spray volume of $130 \mathrm{~L} \mathrm{ha}^{-1}$. The application of the growth regulator was made when plants were in the flower differentiation period, when the first visible node appeared (stage 6.0). The cultivars show an average cycle and a maturation of around 145 days. They are moderately resistant to lodging, and TBIO Itaipú and TBIO Iguaçú cultivars have a medium/high stature. On the other hand, TBIO Master cultivar has a short stature.

Stem diameter (SD), length of the first internode (L1I), length of the second internode (L2I), length of the third internode (L3I), culm length (CL), ear length (EL), number of earlets per ear (EE), mass ear (EM), thousand grain mass (TGM), plant's biomass (PB) and apparent harvest index (AI) were evaluated. The SD was evaluated using a digital caliper, with which two measurements in the middle of the first internode were made. The results were expressed in $\mathrm{mm}$ seedling ${ }^{-1}$. For the evaluation of $\mathrm{L} 1 \mathrm{I}$, L2I and L3I, a ruler graduated in centimeters was used. It measured from the middle of the first node to the middle of the second node, from the middle of the second node to the middle of the third node, from the middle of the third node to the middle of the fourth node, and so on.

To evaluate $C L$, the distance from the plant neck to the base of the ear was measured with the aid of a ruler graduated in centimeters, and the results were expressed in $\mathrm{cm}$ seedling ${ }^{-1}$. To evaluate $\mathrm{EL}$, a ruler graduated in centimeters, measuring from the base of the ear of the main culm to the tip of the ear, excluding the awns was used.

EE was determined by counting the number of earlets from the ear of the main culm. To determine EM, the ears were detached from the samples and the mass was measured with an analytical balance. The results were expressed in $\mathrm{g} \mathrm{ear}^{-1}$. The TGM was determined by counting a thousand grains collected at random from the total production of the plant. To evaluate $\mathrm{PB}$, the shoot of wheat plants was removed by cutting it close to the ground and placing it in an oven at $65^{\circ} \mathrm{C}$ until it reached a constant weight (48 hours). Al, expressed in \%, was calculated by the ratio between the total biomass of the plant and the seed yield.

The grain yield was determined to allow the calculation of the Al. It was conducted by collecting the plants contained in the four central rows of each plot. After the manual sorting, the mass of grains was measured and the data transformed into $\mathrm{kg} \mathrm{ha}^{-1}$ with $13 \%$ moisture.

All variables mentioned above were determined at harvest. The harvest was held on October 20, 2012, at the time the grains have reached maturity (stage 11.4).

The data were submitted to statistical analysis through the software Statistical Analysis System Learning Edition 8.0 (SAS, 2003). Those variables, in which the hypothesis of equality was rejected at a $5 \%$ level of error probability, were compared by a Tukey test for the factors cultivar and growth retardant and regression for $\mathrm{N}$ dose.

\section{Results and discussions}

Figure 1 describes the precipitation values and the average daily temperature that occurred during the growing cycle of the wheat. For precipitation, it can be seen that, throughout the cycle, $605 \mathrm{~mm}$ of rain were recorded. Thus, the culture's water needs were met, not interfering with its development (Libardi \& Costa, 1997). On June 6, 7 and 8,2012 , there were frosts, and they did not influence the development of culture, since it had not yet emerged.

The interactions cultivar- $\mathrm{N}$ level (CxD), $\mathrm{N}$ dose and growth retardant (DxR) were not significant for any of the analyzed variables, since the interaction between cultivar and growth retardant (CxR) presented a significance for SD, L1I, L2I, L3I, TGM, $\mathrm{PB}$ and EE variables (Table 1).

The application of the growth retardant was responsible for the reduction of $12.8 \%$ of the $\mathrm{CL}$ (Table 2). Regarding cultivars, the highest values of this variable were found for TBIO Iguaçú, followed by TBIO Mestre and TBIO Itaipú, and this same order was observed for the EM variable.

The use of a growth retardant increased SD only for TBIO Itaipú cultivar (Table 3). These results corroborate those by Zagonel et al. (2002a), who found a higher SD in wheat culture when subjected to the application of trinexapac-ethyl retardant at different doses of $\mathrm{N}$. Similarly, Lozano \& Leaden (2001) found an increased thickening of the sclerenchyma, which resulted in an increased culm diameter after the application of the same growth retardant in two wheat cultivars. 


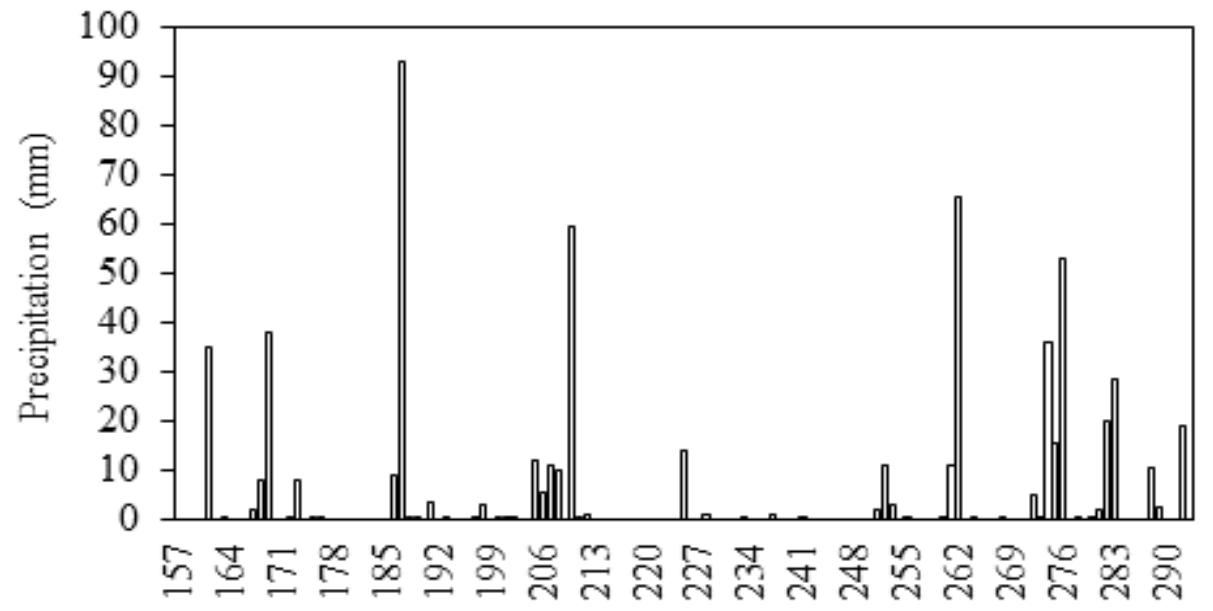

Julian day

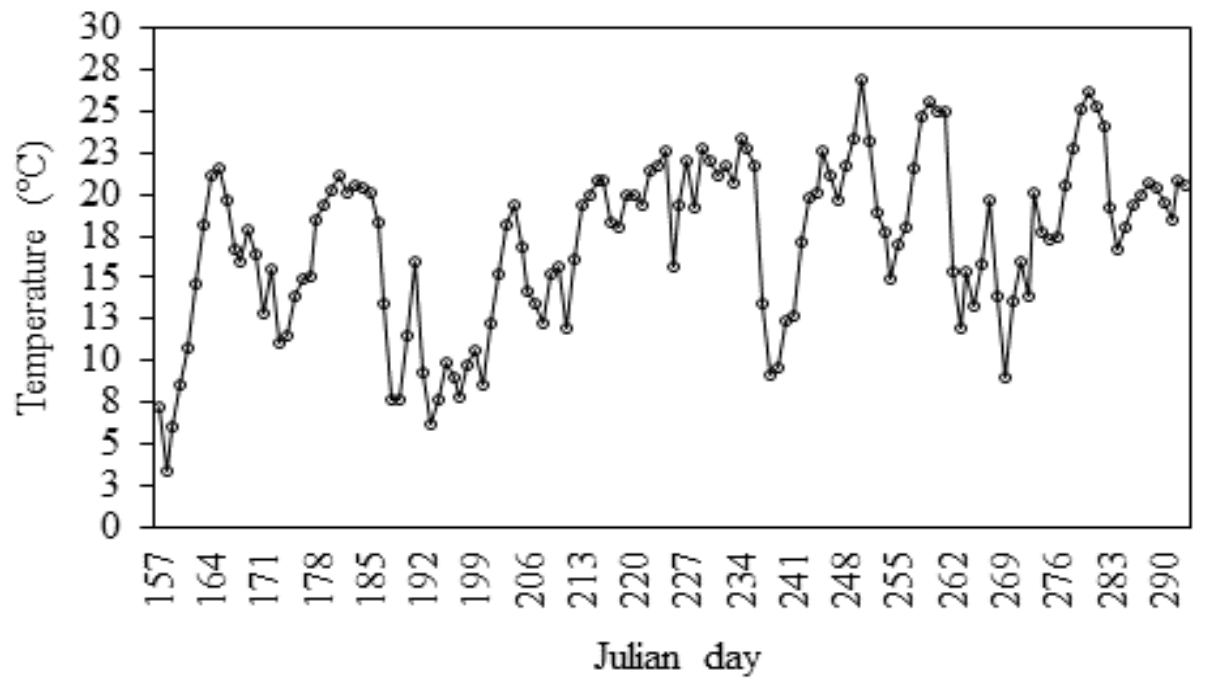

Figure 1 - Precipitation and average daily temperature during the experiment period (06/06/2012 to 10/20/2012), in the city of Frederico Westphalen - RS. UFSM/CESNORS campus Frederico Westphalen - RS, 2012

Table 1 - Analysis of variance for the variables stem diameter (SD; mm), length of the first internode (L1l; $\mathrm{cm})$, length of the second internode $(\mathrm{L} 2 \mathrm{l} ; \mathrm{cm})$, length of the third internode $(\mathrm{L} 3 \mathrm{l} ; \mathrm{cm})$, culm length $(\mathrm{CL} ; \mathrm{Cm})$, ear length $(E L ; \mathrm{cm})$, earlets per ear (EE), ear mass (EM; g), thousand grains mass (TGM; g), plant's biomass (PB; g) and apparent harvest index ( $\mathrm{Al} ; \%$ ) of wheat cultivars in response to $\mathrm{N}$ doses and the use or not of a growth retardant, UFSM/CESNORS, Frederico Westphalen Campus - RS, 2012.

\begin{tabular}{cccccccccc}
\hline \multicolumn{10}{c}{ Medium square } \\
\hline Factor & Cultivar (C) & N Dose (D) & Retardant (R) & C x D & C x R & D x R & C x D $\times$ R & $r^{2}$ & CV \\
\hline SD & $0.01^{*}$ & $0.05^{\text {ns }}$ & $0.02^{*}$ & $0.08^{\text {ns }}$ & $0.02^{*}$ & $0.01^{\text {ns }}$ & $0.07^{\text {ns }}$ & 0.73 & 0.96 \\
L1I & $32.86^{*}$ & $1.02^{*}$ & $0.05^{\text {ns }}$ & $0.98^{\text {ns }}$ & $2.42^{*}$ & $0.33^{\text {ns }}$ & $0.27^{\text {ns }}$ & 0.76 & 9.69 \\
L2I & $23.84^{*}$ & $2.06^{*}$ & $16.79^{*}$ & $0.45^{\text {ns }}$ & $2.72^{*}$ & $0.41^{\text {ns }}$ & $0.93^{\text {ns }}$ & 0.67 & 8.48 \\
L3I & $8.33^{*}$ & $5.28^{*}$ & $66.07^{*}$ & $0.82^{\text {ns }}$ & $29.36^{*}$ & $1.49^{\text {ns }}$ & $0.44^{\text {ns }}$ & 0.66 & 8.66 \\
CL & $193.40^{*}$ & $137.16^{*}$ & $1503.11^{*}$ & $7.64^{\text {ns }}$ & $24.78^{\text {ns }}$ & $22.15^{\text {ns }}$ & $4.40^{\text {ns }}$ & 0.64 & 8.55 \\
EL & $63.53^{\text {ns }}$ & $261.68^{*}$ & $5.09^{\text {ns }}$ & $41.67^{\text {ns }}$ & $83.31^{\text {ns }}$ & $77.19^{\text {ns }}$ & $25.35^{\text {ns }}$ & 0.53 & 9.02 \\
EE & $21.92^{*}$ & $12.31^{\text {ns }}$ & $43.59^{*}$ & $5.97^{\text {ns }}$ & $4.94^{*}$ & $13.97^{\text {ns }}$ & $17.77^{*}$ & 0.55 & 20.49 \\
EM & $0.09^{*}$ & $0.27^{*}$ & $0.02^{\text {ns }}$ & $0.02^{\text {ns }}$ & $0.01^{\text {ns }}$ & $0.01^{\text {ns }}$ & $0.05^{\text {ns }}$ & 0.51 & 12.42 \\
TGM & $1.81^{\text {ns }}$ & $0.83^{\text {ns }}$ & $12.42^{*}$ & $1.12^{\text {ns }}$ & $3.75^{*}$ & $1.48^{\text {ns }}$ & $1.26^{\text {ns }}$ & 0.49 & 6.04 \\
PB & $1.80^{\text {ns }}$ & $0.83^{\text {ns }}$ & $12.42^{*}$ & $1.12^{\text {ns }}$ & $3.75^{*}$ & $1.48^{\text {ns }}$ & $1.26^{\text {ns }}$ & 0.48 & 6.04 \\
Al & $6772.93^{\text {ns }}$ & $100664.75^{\text {ns }}$ & $23817.06^{*}$ & $4452.42^{\text {ns }}$ & $1221.02^{\text {ns }}$ & $6212.34^{\text {ns }}$ & $4069.41^{\text {ns }}$ & 0.66 & 14.02 \\
\hline
\end{tabular}

* Significant at a 5\% level of error probability; ns: not significant at a $5 \%$ level of error probability; $r^{2}$ : coefficient of determination; CV: coefficient of variation (\%). 
Table 2 - Culm length (CL) and ear mass (EM) in wheat cultivars, and in response to the use or not of a growth retardant, UFSM/CESNORS, Frederico Westphalen Campus - RS, 2013.

\begin{tabular}{llll}
\hline & Variables & CL & EM \\
\hline \multirow{2}{*}{ Retardant } & With & $55.6 \mathrm{~b}$ & - \\
& Without & $63.7 \mathrm{a}$ & - \\
\hline \multirow{3}{*}{ Cultivar } & TBIO Mestre & $59.8 \mathrm{ab}$ & $1.33 \mathrm{ab}$ \\
& TBIO Itaipú & $57.0 \mathrm{~b}$ & $1.28 \mathrm{~b}$ \\
& TBIO Iguaçú & $62.1 \mathrm{a}$ & $1.39 \mathrm{a}$ \\
\hline
\end{tabular}

Means followed by the same letter in the column do not differ by Tukey test at $5 \%$ error probability.

Table 3 - Culm diameter (CD; $\mathrm{Cm}$ ), length of the first internode (L1l; $\mathrm{Cm})$, length of the second internode (L2I; $\mathrm{cm}$ ), length of the third internode ( $\mathrm{L} 3 \mathrm{I} ; \mathrm{cm})$, thousand grains mass (TGM; $\mathrm{g}$ ), plant's biomass (PB; g) and earlets per ear (EE) of wheat cultivars (TBIO Mestre, TBIO Itaipú and TBIO Iguaçú) in response to the use or not of the growth retardant, UFSM/CESNORS, Frederico Westphalen Campus - RS, 2013.

\begin{tabular}{|c|c|c|c|c|}
\hline \multirow{2}{*}{ Variables } & \multirow{2}{*}{ Retardant } & \multicolumn{3}{|c|}{ Cultivar } \\
\hline & & TBIO Mestre & TBIO Itaipú & TBIO Iguaçú \\
\hline \multirow{2}{*}{$C L$} & With & 2.55 a B & 2.60 a A & $2.53 \mathrm{a} \mathrm{C}$ \\
\hline & Without & $2.54 \mathrm{a} A$ & $2.52 \mathrm{~b} \mathrm{~B}$ & $2.52 \mathrm{a} B$ \\
\hline \multirow{2}{*}{ L1I } & With & 8.16 a $A$ & 5.97 a C & $7.52 \mathrm{a} \mathrm{B}$ \\
\hline & Without & $7.51 \mathrm{a} \mathrm{B}$ & $6.01 \mathrm{a} \mathrm{C}$ & $8.01 \mathrm{a} \mathrm{A}$ \\
\hline \multirow{2}{*}{ L2I } & With & 10.77 a A & 8.74 b B & $10.18 \mathrm{~b} \mathrm{~A}$ \\
\hline & Without & 10.94 a B & 9.86 a B & 11.47 a A \\
\hline \multirow{2}{*}{ L3I } & With & 14.59 a $A$ & $12.47 \mathrm{~b} \mathrm{~B}$ & $13.88 \mathrm{~b} \mathrm{~A}$ \\
\hline & Without & 14.06 a B & 15.71 a A & 16.32 a $A$ \\
\hline \multirow{2}{*}{ TGM } & With & 252.89 a B & 257.7 a B & 293.24 a A \\
\hline & Without & 245.95 a A & 247.68 a A & 264.95 b A \\
\hline \multirow{2}{*}{ PB } & With & 17.05 a A & 15.92 b B & 16.6 a $A B$ \\
\hline & Without & 17.31 a A & 17.49 a A & 17.05 a A \\
\hline \multirow{2}{*}{ EE } & With & 12.63 a C & 12.91 a B & 15.63 a A \\
\hline & Without & 11.64 a $A$ & 11.94 a A & $12.74 \mathrm{~b} \mathrm{~A}$ \\
\hline
\end{tabular}

Means followed by the same letter, capital in the column small in the line, do not differ by Tukey test at $5 \%$ error probability.

The application of the retardant did not influence L1I, with a difference only between cultivars (Table 3). In contrast, L2I and L3I variables were influenced by the application of the growth retardant, showing a reduction in cultivars TBIO Itaipú and TBIO Iguaçú values. Similar results were found by other authors, who evaluated the effect of trinexapac-ethyl in wheat and barley cultivars in different locations. They concluded that this retardant reduces significantly the length of internodes (Lozano \& Leaden, 2001; Matysiak, 2006; Zagonel \& Fernandes,2007), and, in soybean, it reduces the plant's height (Linzmeyer Júnior et al., 2008).

In addition, it is noteworthy that the right moment of application of the retardant is of fundamental importance for the occurrence of the expected effect. Thus, it should be noted that, in later applications, after the third node, a marked shortening of the culm may happen, causing the ear to be retained in the leaf of the sheath-flag, which results in problems in blooming and, consequently, in wheat yield (Penckowski et al., 2009).

TBIO Iguaçú cultivar presented higher values of TGM with the use of the growth retardant (Table 3). However, in general, a numerically higher TGM was observed in all varieties when this product was used. According to Zagonel et al. (2002b), TGM is a very important variable, because it is correlated with the productivity of wheat.

TBIO Itaipú cultivar showed a decrease of $1.57 \mathrm{~g}$ in the PB with the application of the growth retardant (Table 3). These results may be explained due to the effect that the retardant provokes in the plant. Usually, the retardants bind themselves to receptors in the plant and trigger a series of cellular changes, which may affect the initiation or the modification of organs and tissues' development, such 
as the stimulation of tillering, the redistribution of biomass with increased roots growth, and the inhibition of elongation of internodes, which may entail a reduction of the plant height (Lozano \& Leaden, 2001; Matysiak, 2006; Berti et al., 2007; Zagonel \& Fernandes, 2007).

Calderini et al. (1997) observed that the increase in grain yield, as well as the production of PB in wheat cultivars, is related to the application or not of the retardant. For, in their absence, higher PB values are obtained. However, the leaf is arranged in the prostrate form, making interception and absorption of photosynthetically active radiation difficult, and consequently the efficiency with which they convert radiant energy into chemical energy.

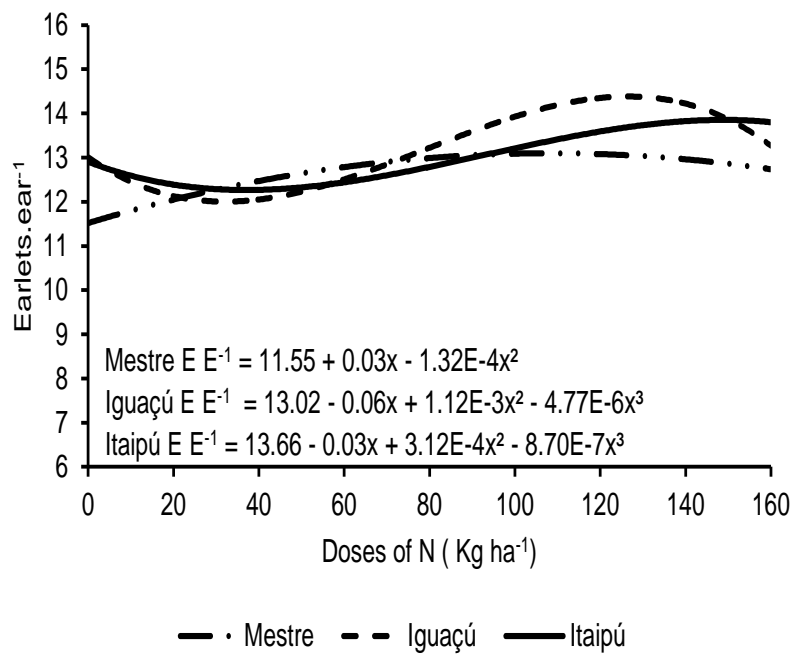

Likewise, Heinemann et al. (2006) point out that, in the presence of the retardant, lower PB values are found. However, the leaf stays in the upright position, absorbing more light, which causes it to produce more tillers and decrease the bedding, as well as obtaining a higher productivity. Therefore, any factor that alters the solar radiation use efficiency may influence the yield of wheat.

TBIO Iguaçú cultivar presented the highest EE value with the use of the growth retardant (Table 3). However, this difference was not observed in the absence of the retardant application among cultivars. Yet, it appears that the addition of $\mathrm{N}$ doses led to an increase in the number of $E E$ in the three cultivars (Figure 2).

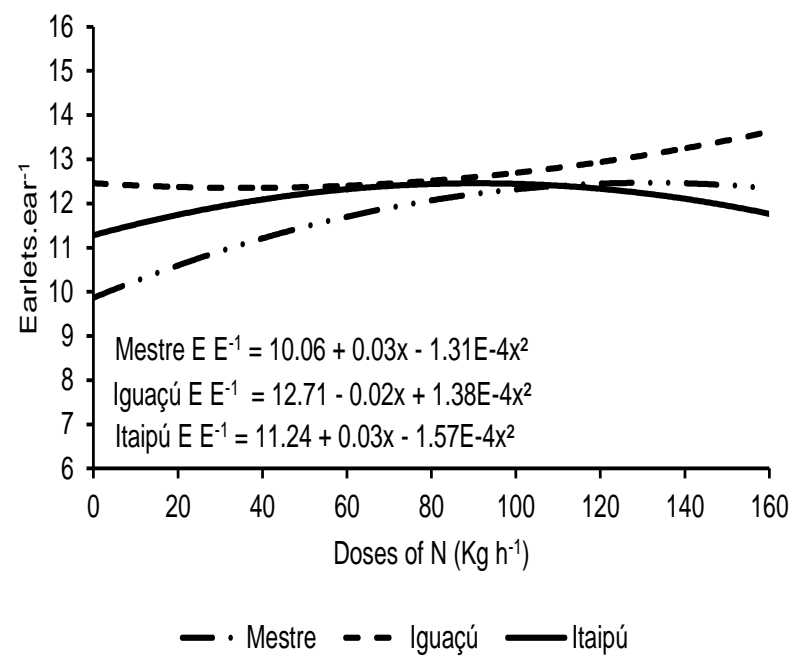

Figure 2 - Regression equations for the number of earlets.ear ${ }^{-1}(\mathrm{EE} ; \mathrm{mm})$ of wheat cultivars under different doses of $\mathrm{N}$ and the use or not of the growth retardant, where $\mathrm{A}=$ with the use of retardant and $\mathrm{B}=$ without the use of retardant. UFSM/CESNORS, Frederico Westphalen campus - RS, 2012.

These results corroborate those reported by Zagonel et al. (2002a), who found that the application of trinexapac-ethyl caused a positive effect on the number of ears per meter, EE and TGM. Likewise, Teixeira Filho et al. (2007), studying the response of four irrigated wheat cultivars in the Cerrado region under different doses of $\mathrm{N}(0,30,60$, 90 and $120 \mathrm{~kg} \mathrm{ha}^{-1}$ ), applied in coverage at 40 days after the emergence of plants, found that $\mathrm{N}$ doses had a significant influence by increasing $E E$.

The increase of the $\mathrm{N}$ doses increased L1I and L3I (Figure 3). These results corroborate those found by Zagonel et al. (2002b), who found that the application of $\mathrm{N}$ enhanced the length of internodes of wheat plants.

The $\mathrm{N}$ doses positively influenced $\mathrm{EL}, \mathrm{CL}$ and EM (Figure 3). There was an adjust to quadratic functions, with the maximum point being achieved with the estimated doses of 140,105 and $108 \mathrm{~kg} \mathrm{ha}^{-1}$ of $\mathrm{N}$, respectively, for $\mathrm{EL}, \mathrm{CL}$ and $\mathrm{EM}$. Likewise, Freitas et al. (1994), studying the responses of grain yield and other agronomic characteristics of different wheat cultivars submitted to nitrogen fertilization, observed an increase in EL related to used $\mathrm{N}$ doses. According to Silva (2010), EL has been considered as an important agronomic trait, because, when associated with other production components (EE, TGM, EM), it is of fundamental importance in order to obtain high culture yields.

\section{Conclusions}

The use of a growth retardant and of increasing doses of $\mathrm{N}$ significantly influences the agronomic characteristics of studied wheat cultivars.

The growth retardant reduces the length of the second and third internodes in TBIO Itaipú and TBIO lguaçú cultivars and the total biomass of the plant, increases the thousand grains mass and increases the number of earlets per ear in TBIO Itaipú cultivar.

The increase of the dose of $\mathrm{N}$ as Sulfammo ${ }^{\circledR}$ enables the increase of the length of the first and third internodes, culm length, ear length and ear mass. 

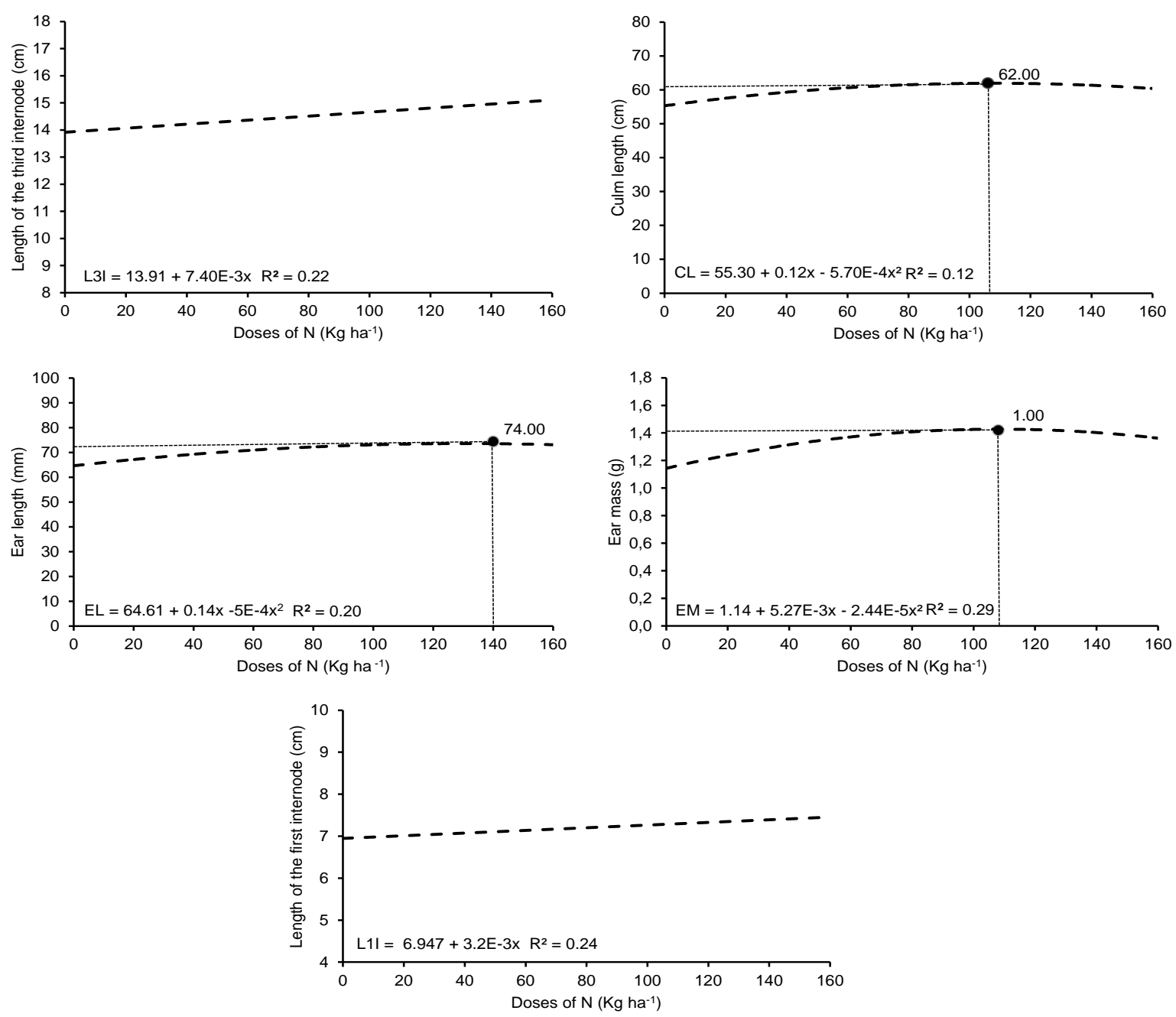

Figure 3 - Regression equations for the variables length of the first internode $(\mathrm{L} 1 \mathrm{l} ; \mathrm{cm})$, length of the third internode $(\mathrm{L} 3 \mathrm{l} ; \mathrm{cm})$, culm length $(\mathrm{CL} ; \mathrm{cm})$, ear length $(\mathrm{EL} ; \mathrm{mm})$ and ear mass $(\mathrm{EM} ; \mathrm{g})$ of wheat cultivars submitted to different doses of N. UFSM/CESNORS, Frederico Westphalen campus - RS 2012.

\section{References}

Berti M, Zagonel J, Fernandes EC (2007) Produtividade de cultivares de trigo em função do trinexapac-ethyl e doses de nitrogênio. Scientia Agraria, 8(2):127-134.

Calderini DF, Dreccer FM, Slafer GA (1997) Consequences of breeding on biomass, radiation interception and radiation-use efficiency in wheat. Field Crops Research, 52(3):271-281.

Comissão de química e fertilidade do solo (2004) Manual de adubação e calagem para os estados do Rio Grande do Sul e Santa Catarina. Porto Alegre: Sociedade Brasileira de Ciência do Solo - Núcleo Regional Sul, 400p.

CONAB (2013) Produção brasileira de grãos. Disponível em: <http://www.conab.gov.br>. Acesso em: 10 dez. 2013.

Davies PJ (1987) The plant hormones: their nature, occourrence, and functions. In: Davies PJ. Plant hormones and their role in plant growth and development. Nethrlands: Kluwer Academic, p.1-23.

Embrapa (2006) Sistema brasileiro de classificação de solos. 2.ed. Rio de Janeiro, Embrapa Solos, 306p.

Foulkes MJ, Slafer GA, Davies WJ, Berry PM, Sylvester-Bradley R, Martre P, Calderini DF, Griffiths S, Reynolds MP (2011) Raising yield potential of wheat. III. Optimizing partitioning to grain while maintaining lodging resistance. Journal of Experimental Botany, 62(2):469-486.

Freitas JG, Camargo CEO, Felicio JC, Ferreira Filho AWP, Pettinelli Junior A (1994) A Produtividade e resposta de genótipos de trigo ao nitrogênio. Bragantia, 53(2):281-290.

Heckman NL, Elthon TE, Horst GL, Gaussoin RE (2002) Influence of trinexapac-ethyl on respiration of isolated wheat mitochondria. Crop Science, 42(2):423-427. 
Heinemann AB, Stone LF, Didonet AD, Trindade MG, Soares BB, Moreira JAA, Cánovas AD (2006) Eficiência de uso da radiação solar na produtividade do trigo decorrente da adubação nitrogenada. Revista Brasileira de Engenharia Agrícola e Ambiental, 10(2):352-356.

Kutman UB, Yildiz B, Cakmak I (2011) Effect of nitrogen on uptake, remobilization and partitioning of zinc and iron throughout the development of durum wheat. Plant and Soil, 342(2):149-164.

Libardi VCM, Costa MB (1997) Consumo d'água da cultura do trigo (Triticum aestivum L.) Revista Faculdade de Zootecnia Veterinária e Agronomia, 4(1):17-22.

Linzmeyer Júnior $R$, Guimarães VF, Santos $D$, Bencke MH (2008) Influência de retardante vegetal e densidades de plantas sobre o crescimento, acamamento e produtividade da soja. Acta Scientiarum. Agronomy, 30(3):373-379.

Lozano CM, Leaden MI (2001) Novedades sobre el uso de reguladores de crecimiento en trigo. Jornadas de actualización profesional: Trigo, p. 34-35.

Maluf JRT (2000) Nova classificação climática do Estado do Rio Grande do Sul. Revista Brasileira de Agrometeorologia, 8(1):141-150.

Matisyak K (2006) Influence of trinexapac ethyl on growth and development of winter wheat. Journal of Plant Protection Research, 46(2):133-143.

Parry M, Reynolds M, Salvucci M, Raines CA, Andralojc PJ, Zhu XG, Price GD, Condon AG, Furbank RT (2011) Raising yield potential of wheat. II. Increasing photosynthetic capacity and efficiency. Journal of Experimental Botany, 62(2):453-467.

Penckowski LH, Zagone J, Fernandes EC (2009) Nitrogênio e redutor de crescimento em trigo de alta produtividade. Acta Scientiarum. Agronomy, 31(3):473-479.
SAS LE (2003) Getting started with the SAS Learning Edition Cary. 200p.

Silva AH (2010) Avaliação de genótipos de trigo duro quanto à produção de grãos e outros caracteres agronômicos no Estado de São Paulo. UNESP (Tese de Doutorado em Irrigação e Drenagem).

Teixeira Filho MCM, Buzetti S, Alvarez RCF, Freitas JG, Arf O, Sá ME (2007) Resposta de cultivares de trigo irrigado por aspersão ao nitrogênio em cobertura na região do cerrado. Acta Scientiarum. Agronomy, 29(3):421-425.

Vieira RD, Fornasieri D, Minohara L, Bergamaschi MC (1995) Efeito de doses e de épocas de aplicação de nitrogênio em cobertura na produção e na qualidade fisiológica de sementes de trigo. Científica, 23(2):257-263.

Zagonel J, Fernandes EC (2007) Doses e épocas de aplicação de redutor de crescimento afetando cultivares de trigo em duas doses de nitrogênio. Planta Daninha, 25(2):331-339.

Zagonel J, Venancio WS, Kunz RP (2002a) Efeito de regulador de crescimento na cultura do trigo submetido a diferentes doses de nitrogênio e densidades de plantas. Planta Daninha, 20(3):471-476.

Zagonel J, Venancio WS, Kunz RP, Tanamati $H$ (2002b) Doses de nitrogênio e densidades de plantas com e sem um regulador de crescimento afetando o trigo, cultivar OR-1. Ciência Rural, 32(1):25-29.

Zerulla W, Barth $\mathrm{T}$, Dressel J, Erhardt $\mathrm{K}$, Locquenghien $\mathrm{KH}$, Von Pasda $\mathrm{G}$, Rädle $\mathrm{M}$, Wissemeier AH (2001) 3,4 Dimethylpyrazole phosphate (DMPP) a new nitrification inhibitor for agriculture and horticulture: an introduction. Biology and Fertility of Soils, 34(1):79-84. 